\title{
Article \\ Evaluation of Three New Citrus Rootstocks under Boron Toxicity Conditions
}

\author{
Lidia Aparicio-Durán ${ }^{1, *(\mathbb{D})}$, Frederick G. Gmitter, Jr. ${ }^{2}{ }^{\circledR}$, Juan M. Arjona-López ${ }^{1}{ }^{\circledR}$, Jude W. Grosser ${ }^{2}$, \\ Rocío Calero-Velázquez $^{1}$, Áurea Hervalejo ${ }^{1}$ (D) and Francisco J. Arenas-Arenas ${ }^{1}$ \\ 1 Department of Agri-Food Engineering and Technology, Andalusian Institute of Agricultural and Fisheries \\ Research and Training (IFAPA), "Las Torres" Center, Ctra. Sevilla-Cazalla de la Sierra km. 12.2, \\ 41200 Alcalá del Río, Spain; juanm.arjona@juntadeandalucia.es (J.M.A.-L.); \\ rocio.calero@juntadeandalucia.es (R.C.-V.); aurea.hervalejo@juntadeandalucia.es (Á.H.); \\ fjose.arenas@juntadeandalucia.es (F.J.A.-A.) \\ 2 Citrus Research and Education Center, Department of Horticultural Sciences, IFAS, University of Florida, \\ Lake Alfred, FL 33850, USA; fgmitter@ufl.edu (F.G.G.J.); jgrosser@ufl.edu (J.W.G.) \\ * Correspondence: lidia.aparicio@juntadeandalucia.es
}

\section{check for} updates

Citation: Aparicio-Durán, L.; Gmitter, F.G., Jr.; Arjona-López, J.M.; Grosser, J.W.; Calero-Velázquez, R.; Hervalejo, Á.; Arenas-Arenas, F.J. Evaluation of Three New Citrus Rootstocks under Boron Toxicity Conditions. Agronomy 2021, 11, 2490. https://doi.org/10.3390/ agronomy11122490

Academic Editors: Marco Caruso, Pablo Aleza and Fernando Rivas

Received: 28 October 2021

Accepted: 3 December 2021

Published: 8 December 2021

Publisher's Note: MDPI stays neutral with regard to jurisdictional claims in published maps and institutional affiliations.

Copyright: (c) 2021 by the authors. Licensee MDPI, Basel, Switzerland. This article is an open access article distributed under the terms and conditions of the Creative Commons Attribution (CC BY) license (https:/ / creativecommons.org/licenses/by/ $4.0 /)$.

\begin{abstract}
Boron (B) toxicity is a common limiting factor both in arid and semiarid regions, such as the Mediterranean Basin. Citrus trees are sensitive to B-toxicity, which generates a negative impact in citrus orchards. In this work, two promising citrus rootstocks (UFR-6 and 2247 x 6070-02-2) have been assessed against B-toxicity and compared with Carrizo citrange, a common commercial citrus rootstock in Mediterranean Basin. Three B concentration treatments (Control, 1 and $2.5 \mathrm{mM} \mathrm{H}_{3} \mathrm{BO}_{3}$ ) were established, irrigating the plants three times per week for 21 days under greenhouse conditions. During the assay, above-ground symptoms, and chlorophyll index (SPAD) were recorded. At the end of the experiment, stomatal conductance, relative water content, and B concentration in leaves and roots were determined. The increasing $B$ concentration in plants generates visual damage in leaves for all citrus rootstocks assayed. Carrizo citrange displayed the greatest visual symptoms, decreased its chlorophyll index (SPAD), and stomatal conductance throughout the B-treatment. However, UFR-6 and $2247 \times 6070-02-2$ displayed less symptoms than Carrizo citrange and only reduced its parameters under the $2.5 \mathrm{mM} \mathrm{H}_{3} \mathrm{BO}_{3}$ treatment. These results can aid citrus grower rootstock planting decisions with under B-toxicity conditions.
\end{abstract}

Keywords: B-excess; HLB; stomatal conductance; RWC; UFR-6

\section{Introduction}

The Mediterranean Basin is the second largest citrus producing region in the world, with an overall production more than 26 million tons [1]. However, numerous factors are threatening Mediterranean citriculture. Desertification and climate change create a hostile environment for citrus crops [2-4].

Boron (B) is an essential element for plants; this micronutrient is necessary for regular growth and development $[5,6]$. However, B excess can easily occur due to small differences between optimal levels and toxicity [7], after the application of fertilizers with excess of this element and/or the continual irrigation with water of high B concentration [8]. Thus, B-toxicity is more frequent in arid and semiarid regions, such as the Mediterranean Basin, in which citrus are a major crop [8,9]. Citrus trees are considered sensitive to B excess; thus, a B concentration above of $0.3 \mathrm{mg} \mathrm{L}^{-1}$ can result in phytotoxicity and reduced yields $[10,11]$. High B levels in citrus leaves lead to visual symptoms in mature, or even young, leaves and also produce premature abscission $[9,12,13]$. As a plant micronutrient, B is involved in several biochemical and physiological essential processes, which can be altered in case of excess. Thus, B-toxicity has an effect on plant growth [14], uptake of other micro- and macro- elements [15], photosynthesis [16,17], and chlorophyll and carotenoid levels [16,18]. 
In this context, there is a necessity to find sustainable methods for Mediterranean citriculture that can solve abiotic disorders, which limit citrus crops, such as boron toxicity. Diversification and accurate choice of citrus rootstocks can be a significant method to reduce abiotic stress [19,20]; even this methodology can improve the citrus industry [21]. Thus, suitable citrus rootstocks selection has a positive impact on field performance, improving and/or maintaining plant growth and fruit production and quality [22]. Nevertheless, the Mediterranean Basin citriculture is often a monoculture orchard, where $61 \%$ of citrus crops in Spain used Carrizo citrange [23]. Carrizo citrange is boron excess sensitive [5]. Consequently, the University of Florida Citrus and Research Education Center (CREC) is obtaining new citrus rootstocks with tolerance against abiotic and biotic stress from their breeding programs. These new citrus rootstocks require characterization under abiotic and biotic limiting factors outside of Florida for Mediterranean Basin growers. The focus of this work was an evaluation of two new promising citrus rootstocks against boron toxicity.

\section{Materials and Methods}

\subsection{Plant Material and Experimental Conditions}

Two new citrus rootstocks recently obtained from the CREC breeding program, UFR-6 ('Changsha' mandarin + Trifoliate orange 50-7), a commercial rootstock with small tree size, notable fruit quality and low HLB sensitivity in the field [24] and $2247 \times 6070-02-2$ ['Nova' + HBP $\times$ Sour orange + Poncirus trifoliata (var. Monstrosa)], an unreleased selection that has displayed low HLB sensitivity in the field (F. G. Gmitter Jr. and J. W. Grosser personal communication), were assayed against boron toxicity conditions. Carrizo citrange (Citrus sinensis L. Osb. $\times$ Poncirus trifoliata L. Raf.) was used as the reference rootstock due to its prevalence in Mediterranean Basin orchards. Six-month-old citrus plants belonging to these three citrus rootstocks were first obtained from in vitro culture and provided by Agromillora Group nursery (Subirats, Barcelona, Spain).

The experiment was carried out with a total of 72 citrus plants for the 2020 summer season and under greenhouse conditions with environmental control $\left[27^{\circ} \mathrm{C}\right.$ average temperature, $56 \%$ average humidity, and 12:12 h (L:D) photoperiod]. This greenhouse is located in "Las Torres" Center of Andalusian Institute of Agricultural and Fisheries Research and Training (IFAPA), in the municipality of Alcalá del Río, Seville, Spain $\left(37^{\circ} 30^{\prime} 43.3^{\prime \prime} \mathrm{N}\right.$; $5^{\circ} 57^{\prime} 47.4^{\prime \prime} \mathrm{W}$ ). Once all plants were received, each citrus rootstock was transferred to a 1.6-litre pot with silica sand. Plants were acclimated for two weeks and irrigated three times a week, with minor modifications for citrus plants of Hoagland and Arnon solution [25] (3 mM of $\mathrm{KNO}_{3}, 3 \mathrm{mM} \mathrm{Ca}\left(\mathrm{NO}_{3}\right), 1 \mathrm{mM} \mathrm{MgSO}_{4} 7 \mathrm{H}_{2} \mathrm{O}, 1.2 \mathrm{mM} \mathrm{H}_{3} \mathrm{PO}_{3} 85 \%, 20 \mu \mathrm{M}$ Fe-EDDAH, $54.4 \mu \mathrm{M} \mathrm{MnSO}_{4} \mathrm{H}_{2} \mathrm{O}, 7.64 \mu \mathrm{M} \mathrm{ZnSO}_{4} 7 \mathrm{H}_{2} \mathrm{O}, 0.5 \mu \mathrm{M}, \mathrm{CuSO}_{4} 5 \mathrm{H}_{2} \mathrm{O}, 46.25 \mu \mathrm{M}$ $\mathrm{H}_{3} \mathrm{BO}_{3}, 0.55 \mu \mathrm{M} \mathrm{MoO}_{3}$ ). To prepare a stock solution, all nutritive reagents were weighted using a digital scale (COBOS precision, CB-3000C, L'Hospitalet de Llobregat, Barcelona, Spain) and dissolved in a tank in the laboratory; lastly, this primary solution was diluted in the greenhouse before the irrigation process.

\subsection{Treatments and Experimental Design}

Three B-toxicity treatments were established in this experiment (Control, 1 and $2.5 \mathrm{mM}$ $\mathrm{H}_{3} \mathrm{BO}_{3}$ ) under a factorial experimental design with a random distribution of four block repetitions constituted by an eight-plant elemental plot $(n=8)$. The experiment began after acclimation on the first day (D1) of treatment application, using eight plants per rootstock and treatment. Each plant was irrigated with $500 \mathrm{~mL}$ of Hoagland and Arnon solution Monday, Wednesday, and Friday during the assay. The three treatments were prepared separately in a specific tank using nutritive solution amended with each boron concentration above. 


\subsection{Evaluation of Plant Symptoms Caused by Boron Toxicity}

For each rootstock/plant and treatment, symptoms in above-ground leaves were evaluated to estimate the effect of the different boron treatments using a symptoms scale of 0-4: plants without symptoms $=0$; plants with $25 \%$ leaves affected by chlorosis $=1$; $50 \%$ leaves affected by chlorosis $=2$; over $50 \%$ leaves affected by chlorosis $=3$; and fully desiccated and dead plants $=4$. This evaluation process was carried out on days $1,10,15$ and 21, starting from the first B treatment application until the end of the assay (when the plants started the defoliation process). The values obtained from this evaluation process were used to calculate the standardized area under the abiotic stress progress curve (SAUASPC, [26]), which increases in the same proportion as the symptom scale.

\subsection{Chlorophyl Index (SPAD)}

The leaf chlorophyll index was measured in all plants assayed by a SPAD chlorophyll meter (Minolta Co., Osaka, Japan). Two expanded leaves per plant were measured on four different evaluation days $(1,10,15$ and 21$)$.

\subsection{Water Status}

\subsubsection{Stomatal Conductance}

Stomatal conductance was studied at the end of the experiment (D21) in a total of four plants per each citrus rootstock and treatment. A Leaf Porometer SC-1 (Decagon Devices, Pullman, WA, USA) was used to perform this evaluation process [27].

\subsubsection{Relative Water Content}

As stated above, relative water content (RWC) was estimated at the end of experiment (D21). For this process, two mature and fully expended leaves per plant were selected, with a total of four plants per rootstock and treatment. Then, two discs of $1 \mathrm{~cm}$ in diameter per selected leaf were cut and taken. All four discs obtained per each plant were weighed using a precision digital scale (METTLER TOLEDO AJ100, Columbus, OH, USA). Next, each four-disk group was covered with distilled water for $4 \mathrm{~h}$ at room temperature and weighed again. After this process, each group of discs was placed in labeled paper enveloped, dried in a heater for $24 \mathrm{~h}$ at $80^{\circ} \mathrm{C}$, and finally weighted. The RWC was calculated according to Morgan (1984) [28] with the following equation:

$$
R W C(\%)=\frac{(W-D W)}{(T W-D W)} \times 100
$$

where $W=$ fresh weight of the four discs in each citrus rootstock and treatment, $T W=$ discs turgent weight (after $4 \mathrm{~h}$ in distilled water) and $D W=$ dry weight discs.

\subsection{Boron Concentration in Leaves and Roots}

To obtain the micronutrient concentration, three leaves and three roots for each citrus rootstock and treatment were used for boron study. This analysis was carried out by a commercially certified specific laboratory for agriculture (Laboratorio Agrama S.L., La Rinconada, Seville, Spain). The methodology analysis technique used for boron was inductively coupled plasma optical emission spectroscopy (ICP-OES).

\subsection{Data Analysis}

All data obtained were subjected to analysis of variance (ANOVA) using the STATISTICA 10 software (StatSoft, Palo Alto, CA, USA). Means separation were obtained using Fisher's test $(p<0.05)$. Normality and homogeneity assumptions were tested before ANOVA. Two-way ANOVA analysis was carried out for SAUASPC values and one-way ANOVA for the remaining results obtained. Data of Carrizo citrange under $2.5 \mathrm{mM} \mathrm{H}_{3} \mathrm{BO}_{3}$ treatment is no available for stomatal conductance, RWC and B concentration in leaves due to the lack of plant material. 


\section{Results}

\subsection{Visual Symptoms Caused by Boron Toxicity}

The highest effect on visual symptoms were more visible at the end of the trial (D21). Control plants from all citrus rootstocks did not display any visual symptoms of damage. Only chlorosis symptoms were found in all citrus rootstocks under $1 \mathrm{mM} \mathrm{H}_{3} \mathrm{BO}_{3}$, but leaves defoliation were not detected in any citrus at this treatment. On the other hand, several leaves defoliation were found in Carrizo citrange at the highest boron concentration ( $2.5 \mathrm{mM} \mathrm{H}_{3} \mathrm{BO}_{3}$ ); whereas UFR-6 and $2247 \times 6070-02-2$ showed chlorosis symptoms at this highest concentration, and very slight defoliation symptoms were found for these both citrus rootstocks (Figure 1).

Control

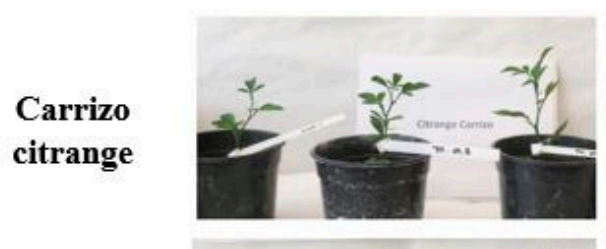

UFR-6

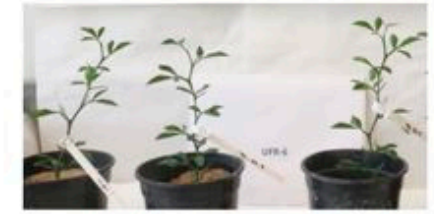

$2247 x$

6070-02-2

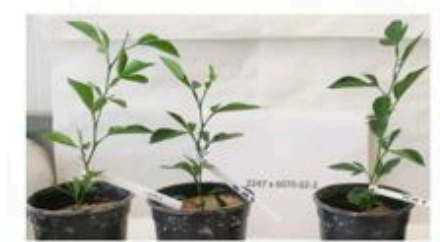

$1 \mathrm{mM} \mathrm{H}_{3} \mathrm{BO}_{3}$
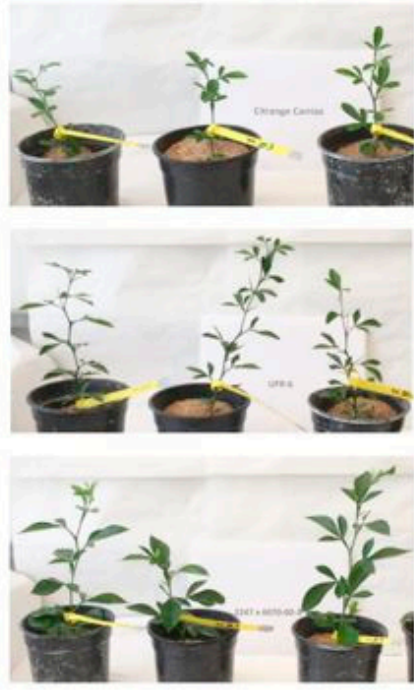

\section{$2.5 \mathrm{mM} \mathrm{H}_{3} \mathrm{BO}_{3}$}
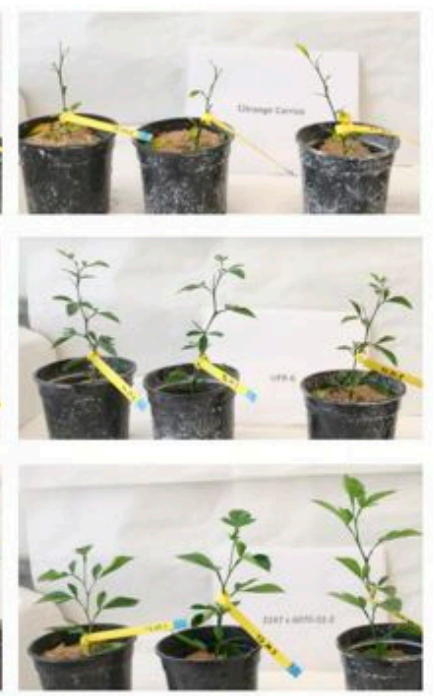

Figure 1. Plant symptoms of the three citrus rootstocks (Carrizo citrange, UFR-6 and 2247 x 6070-02-2) under three boron treatments (Control, $1 \mathrm{mM} \mathrm{H}_{3} \mathrm{BO}_{3}$ and $2.5 \mathrm{mM} \mathrm{H}_{3} \mathrm{BO}_{3}$ ) at the end of the experiment (21 days).

All citrus rootstocks displayed different response. Hence, the highest significant response of SAUASPC was obtained with Carrizo citrange plants under a $2.5 \mathrm{mM} \mathrm{H}_{3} \mathrm{BO}_{3}$ treatment. The SAUASPC response was similar for UFR-6 and $2247 \times 6070-02-2$ under the highest toxicity concentration and was statistically lower compared with the Carrizo citrange and the same treatment. For $1 \mathrm{mM} \mathrm{H}_{3} \mathrm{BO}_{3}$, SAUASPC response in all citrus rootstocks was significantly lower compared with the results at $2.5 \mathrm{mM} \mathrm{H}_{3} \mathrm{BO}_{3}$. Carrizo citrange showed the highest value for $1 \mathrm{mM} \mathrm{H}_{3} \mathrm{BO}_{3}$, with statistical differences compared with the two other citrus rootstocks under the same concentration and with its control. However, UFR-6 and 2247 x 6070-02-2 displayed similar SAUASPC values without significant differences against control treatments (Figure 2). 


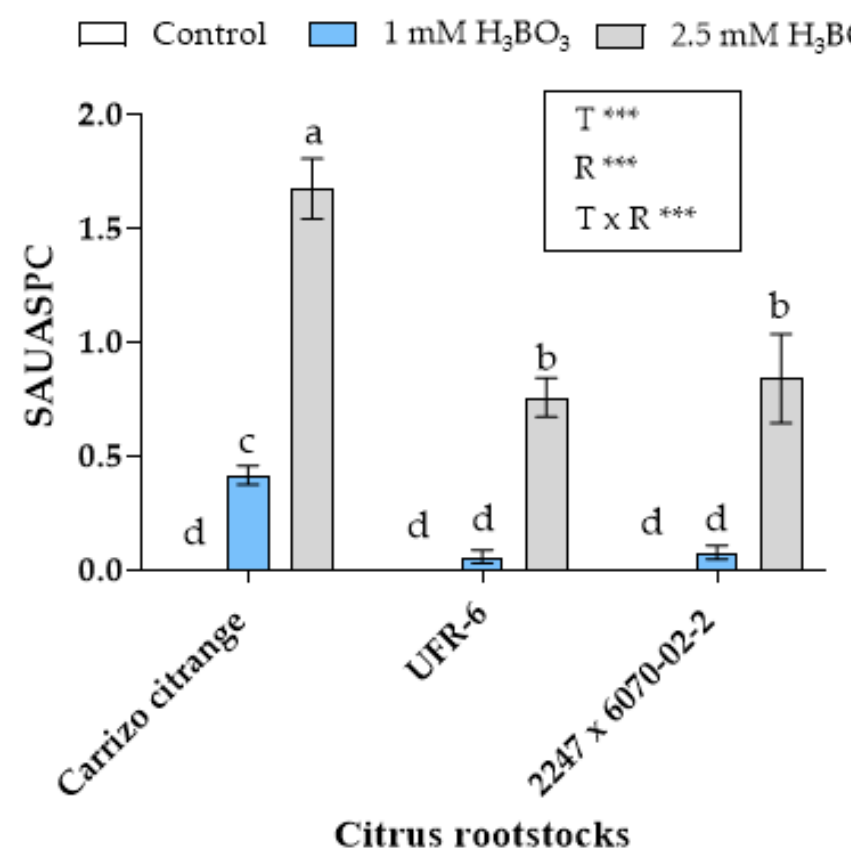

Figure 2. Mean standardized area under the abiotic stress progress curve (SAUASPC) under three toxicity boron treatments (Control, $1 \mathrm{mM} \mathrm{H}_{3} \mathrm{BO}_{3}$, and $2.5 \mathrm{mM} \mathrm{H}_{3} \mathrm{BO}_{3}$ ) on three citrus rootstocks (Carrizo citrange; UFR-6 and 2247 x 6070-02-2) leaves over twenty-one days of treatments. Values in columns with different letters are statistical differences among treatments and rootstock by Fisher LSD test $(p<0.05)$. Significant codes: ${ }^{* * *}=p<0.001$; T: treatment, R: citrus rootstock.

\subsection{Chlorophyll Index (SPAD)}

Carrizo citrange showed similar SPAD values at the first assessment timing for all treatments. However, the $2.5 \mathrm{mM} \mathrm{H}_{3} \mathrm{BO}_{3}$ treatment showed a slight reduction at the D10, decreasing with the lowest SPAD values down to D15, whereas boron treatment of $1 \mathrm{mM} \mathrm{H}_{3} \mathrm{BO}_{3}$ displayed a similar SPAD response to Control until D15. At D21, plants from $1 \mathrm{mM} \mathrm{H}_{3} \mathrm{BO}_{3}$ treatment had reduced SPAD values, and plants treated with $2.5 \mathrm{mM}$ $\mathrm{H}_{3} \mathrm{BO}_{3}$ had slightly increased SPAD values with a similar response to $1 \mathrm{mM}$. In the case of UFR-6, a similar SPAD response was found for all treatments until D10. Plants of this citrus rootstock decreased their SPAD values after D15 with the lowest response at D21. Treatment $1 \mathrm{mM} \mathrm{H}_{3} \mathrm{BO}_{3}$ maintained a similar response to Control plants throughout the assay. Lastly, 2247 x 6070-02-2 displayed a similar SPAD response for all treatments from D1 to 15. Plants of this citrus rootstock had only reduced SPAD response at D21 with the highest concentration treatment (Figure 3). 

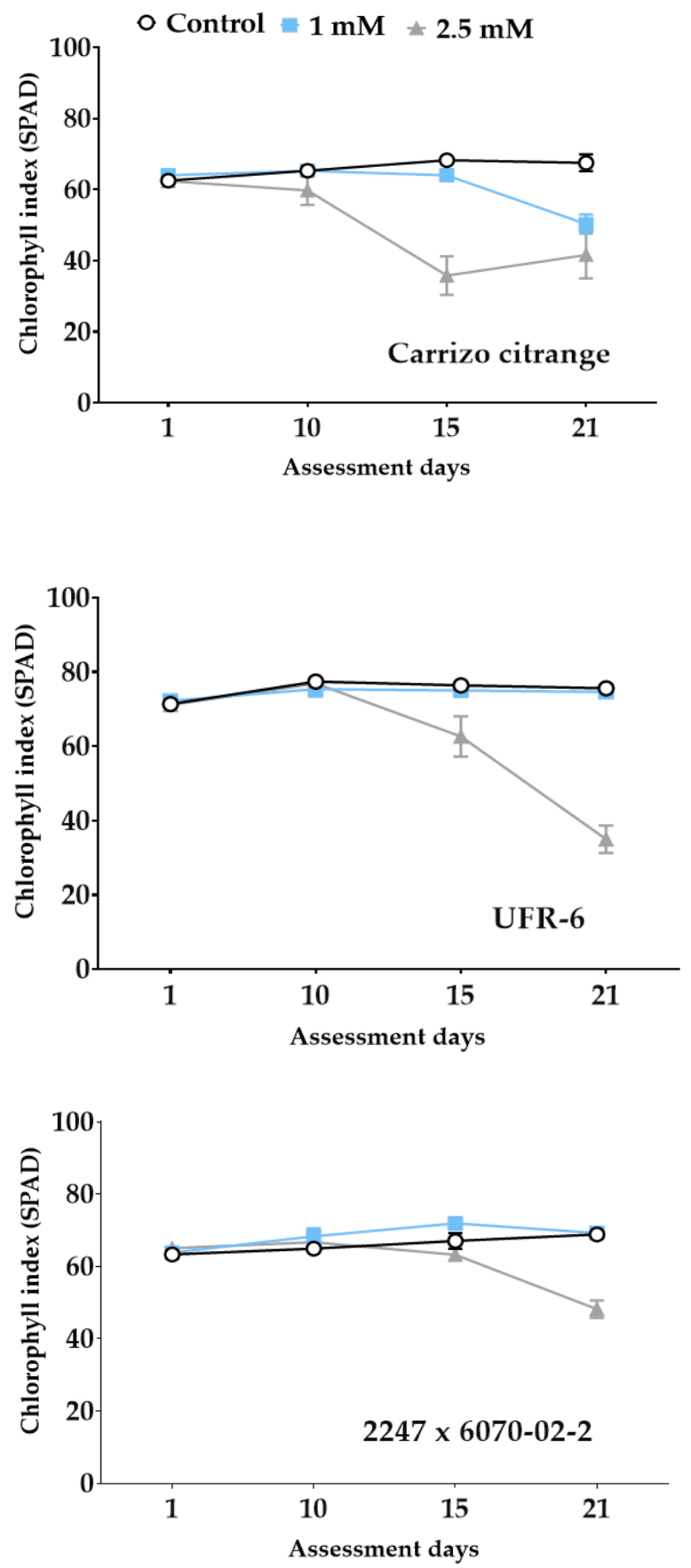

Figure 3. Time course for the mean of chlorophyll index values (SPAD) \pm standard error (SE) with three treatments (Control, $1 \mathrm{mM} \mathrm{H}_{3} \mathrm{BO}_{3}$ and $2.5 \mathrm{mM} \mathrm{H}_{3} \mathrm{BO}_{3}$ ) on three different citrus rootstocks plants (Carrizo citrange, UFR-6 and 2247 x 6070-02-2) during twenty-one days of assessment. 


\subsection{Water Status}

\subsubsection{Stomatal Conductance}

Stomatal conductance response differed among treatments applied for each citrus rootstock. Carrizo citrange displayed a significant reduction in stomatal conductance when boron toxicity increased. Thus, this citrus rootstock displayed significant differences between control treatments and $2.5 \mathrm{mM} \mathrm{H}_{3} \mathrm{BO}_{3}$ treatment. In contrast, neither new citrus rootstock displayed significant differences compared with their respective control plants under $1 \mathrm{mM} \mathrm{H}_{3} \mathrm{BO}_{3}$ and $2.5 \mathrm{mM} \mathrm{H}_{3} \mathrm{BO}_{3}$ treatment. UFR-6 displayed similar values for Control and $1 \mathrm{mM}$ treatment and a slightly higher value in the $2.5 \mathrm{mM}$ treatment, while $2247 \times 6070-02-2$ showed similar values for control and $1 \mathrm{mM} \mathrm{H}_{3} \mathrm{BO}_{3}$ plants, and slightly lower at $2.5 \mathrm{mM} \mathrm{H}_{3} \mathrm{BO}_{3}$ treatment (Figure 4).

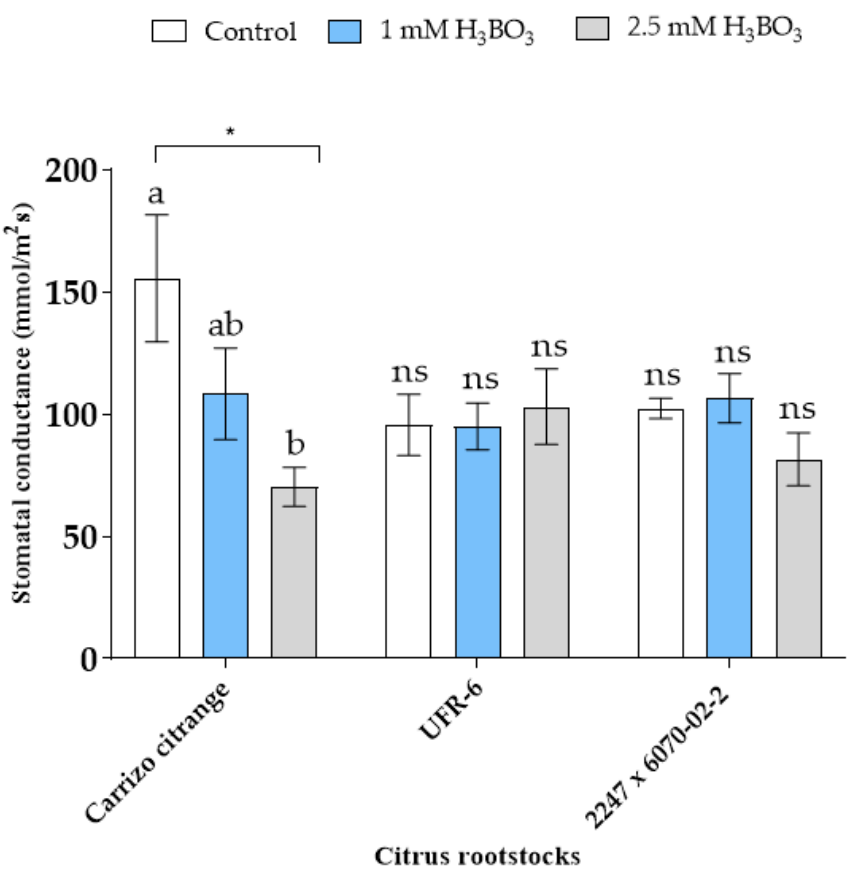

Figure 4. Mean stomatal conductance $\left(\mathrm{mmol} / \mathrm{m}^{2} \mathrm{~s}\right)$ at the end of the experiment with three boron toxicity treatments (Control, $1 \mathrm{mM} \mathrm{H}_{3} \mathrm{BO}_{3}$ and $2.5 \mathrm{mM} \mathrm{H}_{3} \mathrm{BO}_{3}$ ) and using three citrus rootstocks (Carrizo citrange, UFR-6 and $2247 \times 6070-02-2$ ). Values in columns with different letters means statistical differences among the treatments per each rootstock by Fisher LSD test $(p<0.05)$. Significant codes: ${ }^{*}=p<0.05$; ns: non-significant differences.

\subsubsection{Relative Water Content}

RWC did not display high differences among treatments for each citrus rootstock studied. RWC results for Carrizo citrange plants showed a similar behavior between control and $1 \mathrm{mM} \mathrm{H}_{3} \mathrm{BO}_{3}$ treatments without significant differences. In the case of UFR-6, there were no significant differences between control and $1 \mathrm{mM} \mathrm{H}_{3} \mathrm{BO}_{3}$ treatment; however, a slight lower significant RWC was found at $2.5 \mathrm{mM} \mathrm{H}_{3} \mathrm{BO}_{3}$ concentration in this citrus rootstock. Lastly, $2247 \times 6070-02-2$ showed the highest significant RWC values in control treatment, with $1 \mathrm{mM} \mathrm{H}_{3} \mathrm{BO}_{3}$ and $2.5 \mathrm{mM} \mathrm{H}_{3} \mathrm{BO}_{3}$ being significantly lower than control but similar between them (Figure 5). 


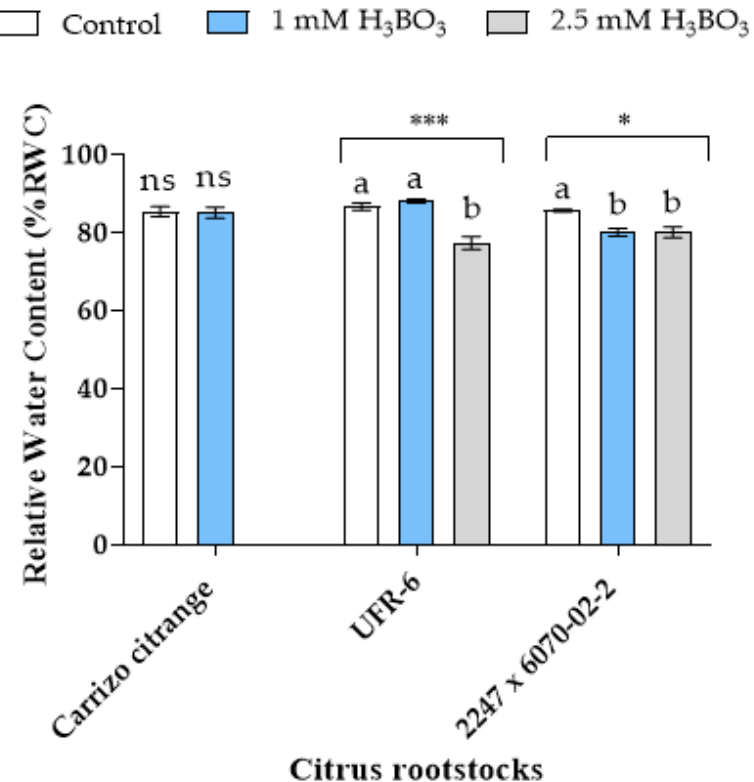

Figure 5. Relative Water Content (RWC) at day 21 of the assay in three citrus rootstocks studied (Carrizo citrange, UFR-6 and $2247 \times 6070-02-2$ ) and under three boron toxicity treatments (Control, $1 \mathrm{mM} \mathrm{H}_{3} \mathrm{BO}_{3}$, and $2.5 \mathrm{mM} \mathrm{H}_{3} \mathrm{BO}_{3}$ ). Values in columns with different letters means statistical differences among treatments for each citrus rootstock by Fisher LSD test $(p<0.05) .2 .5 \mathrm{mM} \mathrm{H}_{3} \mathrm{BO}_{3}$ treatment of Carrizo citrange: data not available. Significant codes: ${ }^{*}=p<0.05$, and ${ }^{* *}=p<0.001$; ns: non-significant differences.

\subsection{Boron Concentration in Plants}

The increase in $\mathrm{B}$ concentration in leaves for all citrus rootstocks was directly proportional to $\mathrm{B}$ toxicity treatments. Carrizo citrange displayed the highest $\mathrm{B}$ concentration values in leaves at $1 \mathrm{mM} \mathrm{H}_{3} \mathrm{BO}_{3}$ treatment with statistical differences compared with its control treatment. UFR-6 displayed the highest $\mathrm{B}$ concentration at $2.5 \mathrm{mM} \mathrm{H}_{3} \mathrm{BO}_{3}$ treatment, with significant differences among $1 \mathrm{mM} \mathrm{H}_{3} \mathrm{BO}_{3}$ and Control treatment. 2247 x 6070-02-2 displayed the highest $\mathrm{B}$ concentration in leaves at $2.5 \mathrm{mM} \mathrm{H}_{3} \mathrm{BO}_{3}$ treatment, followed by $1 \mathrm{mM} \mathrm{H}_{3} \mathrm{BO}_{3}$ and Control, with significant differences among all treatments assayed (Figure 6A).

As with leaves, B concentration in roots increased when the treatment concentration applied was higher. Carrizo citrange displayed highest $\mathrm{B}$ concentrations in roots at $2.5 \mathrm{mM} \mathrm{H}_{3} \mathrm{BO}_{3}$, followed by $1 \mathrm{mM} \mathrm{H}_{3} \mathrm{BO}_{3}$ and Control, with significant differences for each treatment. UFR-6 showed its highest $\mathrm{B}$ concentration at $2.5 \mathrm{mM} \mathrm{H}_{3} \mathrm{BO}_{3}$, having significant differences compared with control, and $1 \mathrm{mM} \mathrm{H}_{3} \mathrm{BO}_{3}$. Finally, $2247 \times 6070-02-2$ displayed the highest $\mathrm{B}$ concentration in roots at the highest dosage applied with significant differences compared with the control and $1 \mathrm{mM} \mathrm{H}_{3} \mathrm{BO}_{3}$ (Figure 6B). 
$\square$ Control $\square 1 \mathrm{mM} \mathrm{H}_{3} \mathrm{BO}_{3} \square 2.5 \mathrm{mM} \mathrm{H}_{3} \mathrm{BO}_{3}$

A

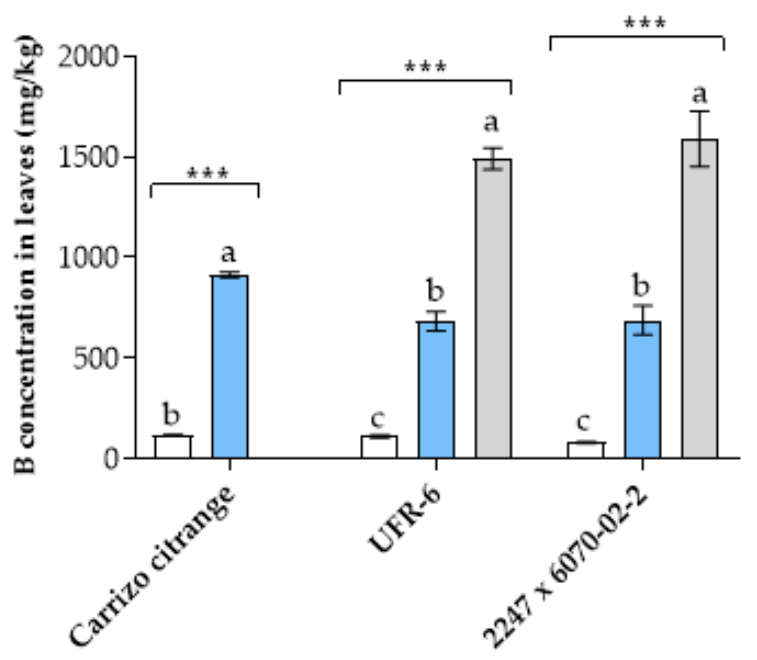

Citrus rootstocks

B

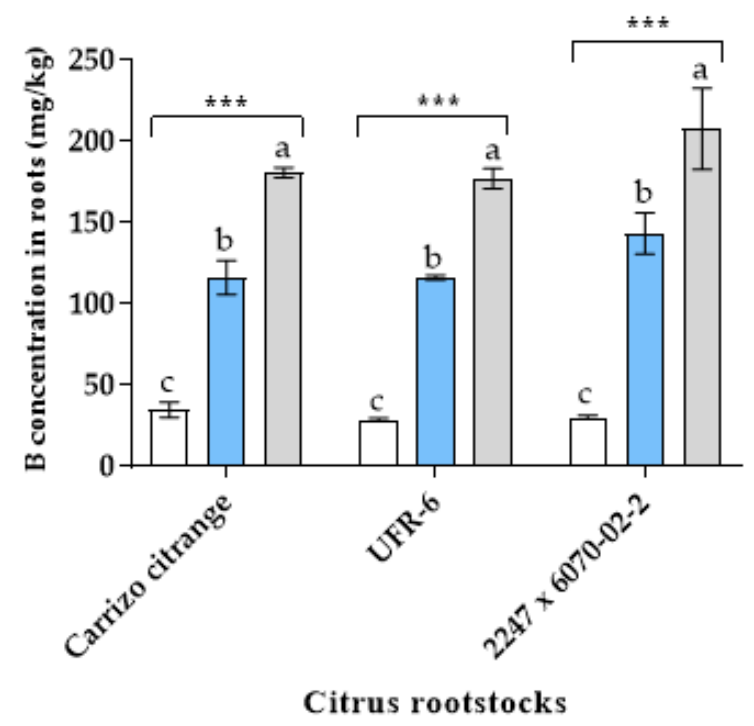

Figure 6. Mean B concentration ( $\mathrm{mg} / \mathrm{kg}$ ) \pm standard error (SE) after twenty-one days for the three rootstocks (Carrizo citrange, UFR-6 and $2247 \times 6070-02-2)$ under three concentrations of boron treatments applied (Control, 1 and $2.5 \mathrm{mM}$ of $\mathrm{H}_{3} \mathrm{BO}_{3}$ ). (A) Mean B concentration in leaves. (B) Mean $\mathrm{B}$ concentration in roots. Values in columns with different letters mean statistical differences among treatments per each rootstock by Fisher's test $(p<0.05) .2 .5 \mathrm{mM} \mathrm{H}_{3} \mathrm{BO}_{3}$ treatment of Carrizo citrange leaves (A): data not available. Significant codes: ${ }^{* *}=p<0.001$; ns: non-significant differences.

\section{Discussion}

The Mediterranean Basin is suffering a desertification process which can lead a B excess, as other arid and semiarid regions in the world. B can be naturally found in groundwater, and the evaporation of this water resource available for plants is increasing in these regions, which generates B-toxicity in the topsoil where crops are grown [2,29-31]. Citrus rootstocks selection can help address the most limiting abiotic and biotic factors, such as B-toxicity. This work provides the citrus industry and breeding programs with information to select the correct citrus rootstock to address B toxicity problems. To our knowledge, these two new citrus rootstocks (UFR-6 and 2247 x 6070-02-2) have never 
been studied under boron toxicity conditions. Citrus plants are known to be sensitive to B-toxicity from soils, irrigation water and fertilization [32], although a different response has been reported depending on the citrus rootstock genotype [33].

$\mathrm{B}$ treatment generated visual symptoms in all citrus rootstocks assayed, but leaf symptoms more intense in Carrizo citrange than in UFR-6 and $2247 \times 6070-02-2$ [34]. SPAD is an indirect measure of chlorophyll index [35]; its assessments provide a numerical measurement of chlorosis [36]. In this study, Carrizo citrange plants displayed the lowest SPAD response after both $\mathrm{B}$ toxicity treatments $\left(1\right.$ and $\left.2.5 \mathrm{mM} \mathrm{H}_{3} \mathrm{BO}_{3}\right)$; additionally, Carrizo citrange exhibited reduced chlorophyll in an early assessment, compared with UFR-6 and $2247 \times 6070-02-2$. These citrus rootstocks showed a similar chlorophyll index (SPAD) under $1 \mathrm{mM} \mathrm{H}_{3} \mathrm{BO}_{3}$ and reducing SPAD under $2.5 \mathrm{mM} \mathrm{H}_{3} \mathrm{BO}_{3}$ treatment. Similar with other reports, the visual symptoms are in accordance with the response of chlorophyll index obtained in this work [37].

Different studies have reported that B-toxicity generates an imbalance in water plant status [38,39]. Hence, stomatal closure is an hormonal response to avoid water loss [12], and this plant process is regulated by abscisic acid (ABA) [40-42]. Under B excess conditions stomatal conductance is reduced in summer squash leaves (Cucurbita pepo L.) [43]. Furthermore, according to prior works under B-toxicity the stomatal closure genotypedependent where citrange plants are known to close their stomates [9,44]. Thus, neither of these promising citrus rootstocks (UFR-6 and $2247 \times$ 6070-02-2) showed reduced stomatal conductance under B-toxicity. RWC indicates reactions and the ability of plants to maintain an optimal water status under stress conditions [45]. According to other studies, salts excess reduces RWC in leaf tissue, as well as B-toxicity in our study [46-48]. Thus, UFR-6 was affected in this parameter at concentration of $2.5 \mathrm{mM} \mathrm{H}_{3} \mathrm{BO}_{3}$ treatment, whereas 2247 $x$ 6070-02-2 responded negatively compared with control in both boron treatment ( 1 and $2.5 \mathrm{mM} \mathrm{H}_{3} \mathrm{BO}_{3}$ ).

B-toxicity in plants is generated by its accumulation in leaves because of high $\mathrm{B}$ concentrations applied and/or long-time exposure. B-toxicity sensitive citrus rootstocks tend to accumulate high concentrations of this microelement in leaves [8]. One characteristic of citrus-tolerant rootstocks against B-toxicity has been reported as the capacity to exclude this compound from leaves; thus, tolerant citrus rootstocks display a lower B concentration in leaves than those susceptible [49]. In our results, UFR-6 and $2247 \times$ 6070-02-2 displayed lower concentration of Boron in leaves than Carrizo citrange under the same concentration of Boron treatment $\left(1 \mathrm{mM} \mathrm{H}_{3} \mathrm{BO}_{3}\right)$. B leaf concentration is not always correlated with other parameters or tolerance responses [50,51]. According to Huang et al. [17], citrus rootstocks with a similar B concentration in leaves and roots could have a sensitive or tolerant response depending on the location where the boron is accumulated. Thus, in our result all citrus rootstocks showed similar response of boron concentration in roots compared with same treatment. $2247 \times 6070-02-2$ displayed the highest concentration response of boron concentration in roots; nevertheless, this citrus rootstock as well UFR-6 displayed only chlorosis symptoms in leaves. This response could be accounted for by the low presence of B in cytoplasm and its movement to the cell wall where B is less toxic $[17,50]$.

\section{Conclusions}

Our results can be useful for better citrus rootstock selection in those regions suffering B toxicity problems. Clearly, UFR-6 and 2247 x 6070-02-2 exhibited better responses compared with Carrizo citrange for most of parameters analysed. These two new promising citrus rootstocks tested (UFR-6 and 2247 x 6070-02-2) could be useful for citrus growers to combat and prevent this abiotic factor in those areas with the above issues. Thus, further research will involve long-term field effect under permanent boron toxicity conditions to confirm these positive results. 
Author Contributions: Conceptualization, F.J.A.-A.; methodology, L.A.-D. and R.C.-V. and F.J.A.A.; software, L.A.-D. and J.M.A.-L.; validation, F.J.A.-A. and J.M.A.-L.; formal analysis, L.A.-D.; investigation, L.A.-D., F.G.G.J., J.W.G. and F.J.A.-A.; resources, F.J.A.-A.; data curation, L.A-D., Á.H. and R.C.-V.; writing - original draft preparation, L.A.-D. and J.M.A.-L.; writing-review and editing, L.A.-D., F.G.G.J., J.M.A.-L., J.W.G., Á.H. and F.J.A.-A.; visualization, F.J.A.-A.; supervision, F.J.A.-A.; project administration, F.J.A.-A.; funding acquisition, F.J.A.-A. All authors have read and agreed to the published version of the manuscript.

Funding: This research was funded by the research contract CEM 38/2018 Agromillora Catalana and the project "Network of Experimentation and Transfer, and the research in Andalusian Citrus (PR.TRA.TRA2019.001.001)", which was co-financed (80\%) by the European Regional Development Fund within the FEDER Operational Program of Andalusia 2014-2020.

Institutional Review Board Statement: Not applicable.

Informed Consent Statement: Not applicable.

Acknowledgments: We are highly thankful to Agromillora Group for providing the plant material. The authors also are grateful to FPI-INIA for the 2016 grant (CPD2016-0130).

Conflicts of Interest: The authors declare no conflict of interest.

\section{References}

1. FAOSTAT. 2021. Available online: http://www.fao.org/faostat/es/\#data/QC (accessed on 15 July 2021).

2. Puigdefábregasa, J.; Mendizabalb, T. Perspectives on desertification: Western Mediterranean. J. Arid. Environ. 1998, 39, 209-224. [CrossRef]

3. López-Bermúdez, F. Soil erosion by water on the desertification of a semi-arid Mediterranean fluvial basin: The Segura basin, Spain. Agric. Ecosyst. Environ. 1990, 33, 129-145. [CrossRef]

4. Ruiz, I.; Almagro, M.; de Jalón, S.G.; Solà, M.D.M.; Sanz, M.J. Assessment of sustainable land management practices in Mediterranean rural regions. J. Environ. Manag. 2020, 276, 111293. [CrossRef] [PubMed]

5. Chen, L.S.; Han, S.; Qi, Y.P. Boron stresses and tolerance in citrus. Afr. J. Biotechnol. 2012, 11, 5961-5969. [CrossRef]

6. Warington, K. The Effect of Boric Acid and Borax on the Broad Bean and certain other Plants 1. Ann. Bot. 1923, 37, 629-672. [CrossRef]

7. Mortvedt, J.J.; Cox, L.M.; Shuman, R.M.W. Micronutrients in Agriculture. Soil Sci. Soc. Am. 1991, 155, 355-356. [CrossRef]

8. Nable, R.O.; Bañuelos, G.S.; Paul, J.G. Boron toxicity. In Plant and Soil; Springer: Dordrecht, The Netherlands, 1997; pp. 181-198.

9. Papadakis, I.E.; Dimassi, K.N.; Therios, I.N. Response of two citrus genotypes to six boron concentrations: Concentration and distribution of nutrients, total absorption, and nutrient use efficiency. Aust. J. Agric. Res. 2003, 54, 571-580. [CrossRef]

10. Sotiropoulos, T.E.; Therios, I.N.; Dimassi, K.N. Calcium application as a means to improve tolerance of kiwifruit (Actinidia deliciosa L.) to boron toxicity. Sci. Hortic. 1999, 81, 443-449. [CrossRef]

11. Grattan, S.; Consultant, C.-S. Evaluation of the Impact of Boron on Citrus Orchards in Riverside County; Riverside County Water Task Force: Riverside, CA, USA, 2013.

12. Papadakis, I.E.; Dimassi, K.N.; Bosabalidis, A.M.; Therios, I.N.; Patakas, A.; Giannakoula, A. Boron toxicity in 'Clementine' mandarin plants grafted on two rootstocks. Plant Sci. 2004, 166, 539-547. [CrossRef]

13. Sheng, O.; Song, S.; Peng, S.; Deng, X. The effects of low boron on growth, gas exchange, boron concentration and distribution of 'Newhall' navel orange (Citrus sinensis Osb.) plants grafted on two rootstocks. Sci. Hortic. 2009, 121, 278-283. [CrossRef]

14. Guo, P.; Qi, Y.-P.; Yang, L.-T.; Ye, X.; Jiang, H.-X.; Huang, J.-H.; Chen, L.-S. cDNA-AFLP analysis reveals the adaptive responses of citrus to long-term boron-toxicity. BMC Plant Biol. 2014, 14, 284. [CrossRef]

15. Sarafi, E.; Siomos, A.; Tsouvaltzis, P.; Therios, I.; Chatzissavvidis, C. The influence of Boron on pepper plants nutritional status and nutrient efficiency. J. Soil Sci. Plant Nutr. 2018, 18, 653-667. [CrossRef]

16. Han, S.; Tang, N.; Jiang, H.-X.; Yang, L.-T.; Li, Y.; Chen, L.-S. $\mathrm{CO}_{2}$ assimilation, photosystem II photochemistry, carbohydrate metabolism and antioxidant system of citrus leaves in response to boron stress. Plant Sci. 2009, 176, 143-153. [CrossRef]

17. Huang, J.-H.; Cai, Z.-J.; Wen, S.-X.; Guo, P.; Ye, X.; Lin, G.-Z.; Chen, L.-S. Effects of boron toxicity on root and leaf anatomy in two Citrus species differing in boron tolerance. Trees 2014, 28, 1653-1666. [CrossRef]

18. Reid, R. Physiology and Metabolism of Boron in Plants. In Advances in Plant and Animal Boron Nutrition; Springer: Dordrecht, The Netherlands, 2007; pp. 83-90. [CrossRef]

19. Bowman, K.D.; McCollum, G.; Albrecht, U. Performance of 'Valencia' orange (Citrus sinensis [L.] Osbeck) on 17 rootstocks in a trial severely affected by huanglongbing. Sci. Hortic. 2016, 201, 355-361. [CrossRef]

20. De Carvalho, L.M.; de Carvalho, H.W.; de Barros, I.; Martins, C.R.; Soares Filho, W.D.S.; Girardi, E.A.; Passos, O.S. New scionrootstock combinations for diversification of sweet orange orchards in tropical hardsetting soils. Sci. Hortic. 2019, 243, 169-176. [CrossRef] 
21. Neto, H.B.; Filho, F.D.A.A.M.; Stuchi, E.S.; Espinoza-Núñez, E.; Cantuarias-Avilés, T. The horticultural performance of five 'Tahiti' lime selections grafted onto 'Swingle' citrumelo under irrigated and non-irrigated conditions. Sci. Hortic. 2013, 150, 181-186. [CrossRef]

22. Syvertsen, J.; Garcia-Sanchez, F. Multiple abiotic stresses occurring with salinity stress in citrus. Environ. Exp. Bot. 2014, 103, 128-137. [CrossRef]

23. Tallón-Villa, C. Biotechnology Applied to the Genetic Improvement of Citrus Rootstocks. Development of a Protocol for Micropropagation and Adventitious Regeneration for Use in Generating Salt Toleran Mutant Lines. Ph.D. Thesis, Universidad de Murcia, Murcia, Spain, 9 November 2015.

24. Grosser, J.W. Citrus Rootstock Named “UFR-6". U.S. Patent PP27,276, 20 August 2015.

25. Hoagland, D.R.; Arnon, D.I. The water-culture method for growing plants without soil. Circ. Calif. Agric. Exp. Stn. 1950, 347, 32

26. Campbell, C.L.; Madden, L.V. Temporal analysis of epidemics I: Descriptions and comparisons of disease progress curve. In Introduction to Plant Disease Epidemiology; Campbell, C.L., Madden, L.V., Eds.; Wiley: New York, NY, USA, 1990; pp. 161-202.

27. Rewald, B.; Raveh, E.; Gendler, T.; Ephrath, J.E.; Rachmilevitch, S. Phenotypic plasticity and water flux rates of Citrus root orders under salinity. J. Exp. Bot. 2012, 63, 2717-2727. [CrossRef]

28. Morgan, J.M. Osmoregulation and Water Stress in Higher Plants. Annu. Rev. Plant Physiol. 1984, 35, 299-319. [CrossRef]

29. Dorta-Santos, M.; Tejedor, M.; Jiménez, C.; Hernández-Moreno, J.M.; Díaz, F.J. Using marginal quality water for an energy crop in arid regions: Effect of salinity and boron distribution patterns. Agric. Water Manag. 2016, 171, 142-152. [CrossRef]

30. Landi, M.; Margaritopoulou, T.; Papadakis, I.E.; Araniti, F. Boron toxicity in higher plants: An update. Planta 2019, 250, 1011-1032. [CrossRef] [PubMed]

31. Tanaka, M.; Fujiwara, T. Physiological roles and transport mechanisms of boron: Perspectives from plants. Pflügers Arch. 2008, 456, 671-677. [CrossRef]

32. Liu, G.-D.; Wang, R.-D.; Liu, L.-C.; Wu, L.-S.; Jiang, C.-C. Cellular boron allocation and pectin composition in two citrus rootstock seedlings differing in boron-deficiency response. Plant Soil 2013, 370, 555-565. [CrossRef]

33. Gimeno, V.; Simón, I.; Nieves, M.; Martinez, V.; Cámara-Zapata, J.-M.; García, A.L.; Garcia-Sanchez, F. The physiological and nutritional responses to an excess of boron by Verna lemon trees that were grafted on four contrasting rootstocks. Trees 2012, 26, 1513-1526. [CrossRef]

34. Ruiz, M.; Quiñones, A.; Martínez-Alcántara, B.; Aleza, P.; Morillon, R.; Navarro, L.; Primo-Millo, E.; Martínez-Cuenca, M.-R. Tetraploidy Enhances Boron-Excess Tolerance in Carrizo Citrange (Citrus sinensis L. Osb. $\times$ Poncirus trifoliata L. Raf.). Front. Plant Sci. 2016, 7, 701. [CrossRef]

35. García-Sánchez, F.; Jifon, J.L.; Carvajal, M.; Syvertsen, J.P. Gas exchange, chlorophyll and nutrient contents in relation to $\mathrm{Na}^{+}$and $\mathrm{Cl}^{-}$accumulation in 'Sunburst' mandarin grafted on different rootstocks. Plant Sci. 2002, 162, 705-712. [CrossRef]

36. Ruiz, M.; Quinones, A.; Martínez-Alcántara, B.; Aleza, P.; Morillon, R.; Navarro, L.; Primo-Millo, E.; Martínez-Cuenca, M.-R. Effects of salinity on diploid $(2 \times)$ and doubled diploid $(4 \times)$ Citrus macrophylla genotypes. Sci. Hortic. 2016, 207, 33-40. [CrossRef]

37. Aparicio-Durán, L.; Hervalejo-García, A.; Calero-Velázquez, R.; Arjona-López, J.M.; Arenas-Arenas, F.J. Salinity Effect on Plant Physiological and Nutritional Parameters of New Huanglongbing Disease-Tolerant Citrus Rootstocks. Agronomy 2021, 11, 653. [CrossRef]

38. Papadakis, I.; Tsiantas, P.; Gerogiannis, O.; Vemmos, S.; Psychoyou, M. Photosynthetic activity and concentration of chlorophylls, carotenoids, hydrogen peroxide and malondialdehyde in loquat seedlings growing under excess boron conditions. Acta Hortic. 2015, 1092, 221-226. [CrossRef]

39. Kaya, C.; Tuna, A.L.; Dikilitas, M.; Ashraf, M.; Koskeroglu, S.; Guneri, M. Supplementary phosphorus can alleviate boron toxicity in tomato. Sci. Hortic. 2009, 121, 284-288. [CrossRef]

40. Nakashima, K.; Ito, Y.; Yamaguchi-Shinozaki, K. Transcriptional Regulatory Networks in Response to Abiotic Stresses in Arabidopsis and Grasses. Plant Physiol. 2009, 149, 88-95. [CrossRef]

41. Macho-Rivero, M.A.; Herrera-Rodríguez, M.B.; Brejcha, R.; Schäffner, A.R.; Tanaka, N.; Fujiwara, T.; González-Fontes, A.; Camacho-Cristóbal, J.J. Boron Toxicity Reduces Water Transport from Root to Shoot in Arabidopsis Plants. Evidence for a Reduced Transpiration Rate and Expression of Major PIP Aquaporin Genes. Plant Cell Physiol. 2018, 59, 841-849. [CrossRef] [PubMed]

42. Macho-Rivero, M.Á.; Camacho-Cristóbal, J.J.; Herrera-Rodríguez, M.B.; Müller, M.; Munné-Bosch, S.; González-Fontes, A. Abscisic acid and transpiration rate are involved in the response to boron toxicity in Arabidopsis plants. Physiol. Plant. 2017, 160, 21-32. [CrossRef] [PubMed]

43. Lovatt, C.J.; Bates, L.M. Early Effects of Excess Boron on Photosynthesis and Growth of Cucurbita pepo. J. Exp. Bot. 1984, 35, 297-305. [CrossRef]

44. Shah, A.; Wu, X.; Ullah, A.; Fahad, S.; Muhammad, R.; Yan, L.; Jiang, C. Deficiency and toxicity of boron: Alterations in growth, oxidative damage and uptake by citrange orange plants. Ecotoxicol. Environ. Saf. 2017, 145, 575-582. [CrossRef] [PubMed]

45. González, L.; González-Vilar, M. Determination of Relative Water Content. In Handbook of Plant Ecophysiology Techniques; Kluwer Academic Publishers: Dordrecht, The Netherlands, 2006; pp. 207-212. [CrossRef]

46. Netondo, G.W.; Onyango, J.C.; Beck, E. Sorghum and Salinity. Crop. Sci. 2004, 44, 797-805. [CrossRef] 
47. Sharif, P.; Seyedsalehi, M.; Paladino, O.; Van Damme, P.; Sillanpää, M.; Sharifi, A.A. Effect of drought and salinity stresses on morphological and physiological characteristics of canola. Int. J. Environ. Sci. Technol. 2017, 15, 1859-1866. [CrossRef]

48. Masood, S.; Saleh, L.; Witzel, K.; Plieth, C.; Mühling, K.H. Determination of oxidative stress in wheat leaves as influenced by boron toxicity and $\mathrm{NaCl}$ stress. Plant Physiol. Biochem. 2012, 56, 56-61. [CrossRef]

49. Reid, R. Can we really increase yields by making crop plants tolerant to boron toxicity? Plant Sci. 2010, 178, 9-11. [CrossRef]

50. Reid, R.; Fitzpatrick, K. Influence of Leaf Tolerance Mechanisms and Rain on Boron Toxicity in Barley and Wheat. Plant Physiol. 2009, 151, 413-420. [CrossRef] [PubMed]

51. Reid, R.; Fitzpatrick, K.L. Redistribution of boron in leaves reduces boron toxicity. Plant Signal. Behav. 2009, 4, 1091-1093. [CrossRef] 